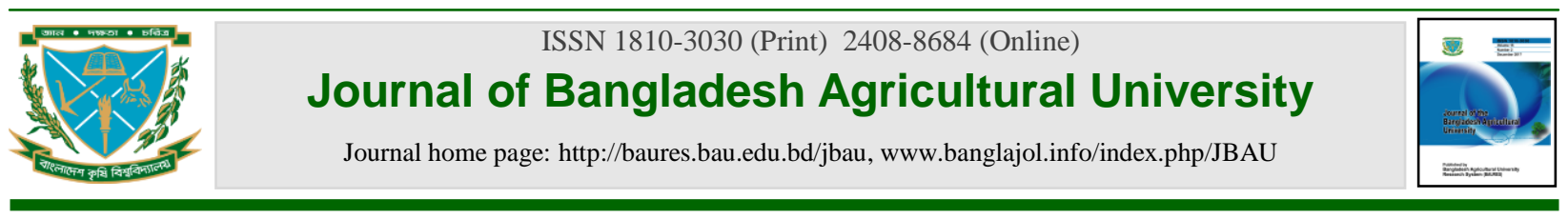

\title{
Managing sustainable Boro rice production through bio-slurry practice in Mymensingh district of Bangladesh
}

\author{
H. Kabir, M. A. Isjam, M. Khan ${ }^{1}$ and R. Rahman ${ }^{2}$ \\ Department of Agricultural Economics, Bangladesh Agricultural University, Mymensingh-2202, Bangladesh \\ ${ }^{1}$ Department of Animal Science, Bangladesh Agricultural University, Mymensingh-2202, Bangladesh \\ ${ }^{2}$ Sheikh Fojilatunnessa Mujib Fisheries College, Jamalpur
}

\begin{tabular}{|c|c|}
\hline ARTICLE INFO & Abstract \\
\hline $\begin{array}{l}\text { Article history: } \\
\text { Received: } 10 \text { October } 2017 \\
\text { Accepted: } 07 \text { December } 2017\end{array}$ & $\begin{array}{l}\text { This study aimed to explore sustainable agricultural land management for Boro rice production through } \\
\text { bio-slurry practice in Bangladesh. Face to face interviews were used on bio-slurry user and non-user } \\
\text { farmers in the selected areas of Mymensingh district. The nutritional values (Nitrogen }(\mathrm{N}) \text {, Phosphorus } \\
\text { (P), and Potassium (K) of the slurry and non-slurry based soil were analyzed in the Department of Soil }\end{array}$ \\
\hline $\begin{array}{l}\text { Keywords: } \\
\text { Sustainable Boro, Production, } \\
\text { Bio-slurry }\end{array}$ & $\begin{array}{l}\text { Science laboratory, BAU. Descriptive statistics were used to estimate the benefit and cost of boro rice } \\
\text { production based on slurry and non-slurry practice. Likert Score scaling and Fishbein model were used to } \\
\text { evaluate social acceptability and perception of slurry practices. Two-t sample test also applied for } \\
\text { significance the difference of N,P, K on slurry based and non-slurry based soil.. Sixty households were } \\
\text { purposively selected and the data were covered on socioeconomic characteristics, consumer attitude, }\end{array}$ \\
\hline $\begin{array}{l}\text { Correspondence: } \\
\text { H. Kabir } \\
\text { (hkabir75@yahoo.com) }\end{array}$ & $\begin{array}{l}\text { income, cost, returns of bio-slurry and non-slurry based crop. The cost of } \mathrm{N}, \mathrm{P}, \mathrm{K} \text { was reduced due to } \\
\text { slurry practices instead of chemical fertilizer practices. The total production cost of boro rice per acre for } \\
\text { slurry and non-slurry practices were BDT } 31,064 \text { and BDT } 34,877 \text { respectively, The per acre net return of } \\
\text { bio-slurry and non-slurry based rice production were BDT } 6056 \text { and BDT } 425 \text { respectively and BCR were } \\
1.19 \text { and } 1.01 \text {, respectively. The bio-slurry practice is much convenient for sustainable land management } \\
\text { because it is economic viable, socially accepted and finally, slurry based soil contains significantly better } \\
\text { Phosphorus and Potassium compared to non-slurry based soil. }\end{array}$ \\
\hline
\end{tabular}

\section{Introduction}

Conventional practice for agricultural production in Bangladesh generates different dimension of environmental difficulties and challenges like, soil erosion, soil acidity, imbalance of nutrients in the soil, biodiversity loss and overall environmental degradation, however one can recognize, it is ultimate result of Green Revolution (Mendoza, 2002). Though touted for its high yields, this production system demonstrated to enhance the above problems. Depletion of organic matter is often an important factor in the process of soil fertility decline. Healthy soil should have an organic matter content of more than 2.5\% (BARC, 2005). Most soil in Bangladesh has less than $1.7 \%$ organic components and in some areas the soil has less than 1\% (Islam, 2006) . This soil health can be geared up by using the bio-slurry. In Bangladesh, major food crops tantamount to 3 million tons nutrient removal annually which is alarming for causing infertility in the soil. Depleted fertility stands against achieving a good return on even adapting intensive cultivation. Hence use of cow dung and poultry manure along with inorganic fertilizer should be the common practice in improving the soil and balancing other macro and micro elements needed by plants (Haque, 2013). Bio-slurry is an anaerobic digested organic material released as byproduct from the biogas plant after production of combustible methane gas for cooking, lighting and running machinery. The undigested slurry undergoes a series of anaerobic digestion processes or fermentation in a biogas digester and is converted into combustible gas called biogas. The residue of the fermentation comes out as sludge which is known as digested bio-slurry. The residue of the fermentation comes out as sludge which is known as digested bio-slurry and nutritional value is greatly improved if urine can also be collected in the digester. Bio-slurry can be used for fertilization of crops directly or added to composting of other organic materials. It is digested source of animal waste, and if urine (animal and/or human) is added, more nitrogen is added to the bio-slurry, which can speed up the compost-making process. It is treated as organic fertilizer which is environmental friendly, has no toxic or harmful effects and can easily reduce the use of chemical fertilizers up to $50 \%$. With the organic resources available every day, it is possible to construct 4 million biogas plants in the country. From these biogas plants a huge quantity of organic fertilizers will be available to supplement chemical fertilizers for land application. Bio-slurry contains appreciable amounts of organic matter (20 to $30 \%$ ) very much needed for our hungry soils. Bio-slurry is alkaline in reaction and has liming effects. It is very useful for reducing harmful effects of aluminum in acid soils. Thus, it can be easily seen that the use of bioslurry has multiple benefits. (Islam, 2006). Therefore, 
this research try to estimate the comparative profitability and productivity of slurry led crops and chemical fertilizer based boro production; and evaluate social acceptability and perception of slurry practices.

\section{Materials and Methods}

Two Upazila namely Mymensingh Sadar and Phulpur under Mymensingh District of which 10 unions from Mymensingh Sadar and 5 unions from Phulpur were selected for this research. In total 60 (sixty) sample households were purposively selected who cultivated rice with slurry practice and non-slurry practice because slurry were not much available for the whole rice crop lands of the households in the study areas. It means each household has slurry based rice cultivation practice and non-slurry based rice cultivation practice. Sixty slurry and non-slurry based soil sample were collected from the selected areas and tested these sample in the Department of Soil Science, BAU, Mymensingh.

Table 1. Distribution of Sample Unit (Household)

\begin{tabular}{llccc}
\hline \multirow{2}{*}{ District } & Upazila & $\begin{array}{c}\text { Slurry } \\
\text { use }\end{array}$ & $\begin{array}{c}\text { Non- } \\
\text { slurry use }\end{array}$ & Total \\
\hline \multirow{4}{*}{ Mymensingh } & Mymensingh & & & \\
& Sadar & 20 & 20 & \\
Total & Phulpur & 40 & 40 & 60 \\
\hline
\end{tabular}

Source: Field survey, 2016

\section{Analytical Techniques}

Both tabular (i.e., average, percentage, ratio, Likert Score scaling, and Fishbein model, etc.) and functional analysis (Two sample t-test) are used for this study.

Gross return, net return per acre and BCR are calculated for Boro rice production to compare the profitability with and with bio-slurry. To evaluate social acceptability and perception of slurry practices Likert score approach and Fishbein model is applied for measuring the acceptability and perception of bio-slurry practices

Mathematical formulation of the model of attitude toward the object, by Fishbein can be formulated as follows:

$$
A_{0}=\sum_{i=1}^{n} b_{i} e_{i}
$$

Where,

$\mathrm{A}_{0}=$ Attitude towards the object;

$\mathrm{n}=$ there are a limited number $(\mathrm{n})$ of attributes which the person will consider;

bi = straight of the salient belief associated towards the objects and $\mathrm{ei}=$ evaluation of the attribute as being good or bad.

And $b_{i}=\sum_{i=1}^{n} \frac{f_{1} i_{1}+f_{2} i_{2}+F_{3} i_{3},-, f_{n} i_{n}}{n}$

Where,

$\mathrm{f}=$ Degree of experience;

$\mathrm{i}=$ Number of person agree of this experience and $\mathrm{n}=$ Total number of farmers.

And

$e_{i}=\sum_{i=1}^{n} \frac{x_{1} i_{1}+x_{2} i_{2}+x_{3} i_{3},-, x_{n} i_{n}}{n}$

Where,

$\mathrm{x}=$ Quantitative value of degree;

$\mathrm{i}=$ Number of person agree of this value; and

$\mathrm{n}=$ Total number of farmers.

Likert scale model were used to evaluate each characteristic (bi) of bio-slurry and chemical fertilizer.

\begin{tabular}{ccccc}
\hline $\begin{array}{l}\text { Strongly } \\
\text { agree }\end{array}$ & Agree & Undecided & Disagree & $\begin{array}{l}\text { Strongly } \\
\text { disagree }\end{array}$ \\
\hline 5 & 4 & 3 & 2 & 1 \\
\hline
\end{tabular}

The consumer provides the following responses, which represent e.i. (an evaluation of the attribute as being good or bad)

\begin{tabular}{lllllll}
+3 & +2 & +1 & 0 & -1 & -2 & -3 \\
\hline
\end{tabular}

To estimate the soil productivity by using the slurry and chemical fertilizers:

The following different methods are being applied for estimating the basic nutrient value like, nitrogen, potassium and phosphorus.

Kjeldahl method, Ammonium extraction method (measurement: Spectrophotpmer) and Calcium chloride extraction method (measurement: Flame photometer) were used for identifying the Nitrogen (N) Phosphorus (P0 and Potassium $(\mathrm{K})$, respectively.

Two sample t-test was applied for estimating the significant differences of N,P, K of slurry based and chemical fertilizer. The two-sample t-test for unpaired data is defined as:

Null hypothesis, $H_{0}: \quad \mu_{1}=\mu_{2}$

Alternative hypothesis, $H_{1}: \quad \mu_{1} \neq \mu_{2}$

Test statistic; $T=\frac{\bar{Y}_{1}-\bar{Y}_{2}}{\sqrt{S_{1}^{2} / N_{1}+S_{2}^{2} / N_{2}}}$

Where, $\mathrm{N}_{1}$ and $\mathrm{N}_{2}$ are the sample sizes, $\bar{Y}_{1}$ and $\bar{Y}_{2}$ the sample means, $S_{1}^{2}$ and $S_{2}^{2}$ are the sample variances. 


\section{Results and Discussion}

The following different components of comparative profitability of slurry and non-slurry based boro rice production have been estimated:

\section{Estimation of Cost}

Cost items of selected farming practices were classified into two major groups, such as: (a) variable cost, and (b) fixed cost. The cost items were classified under the following heads:

(a) Variable cost items for both slurry and non-slurry based crop productions are given below: Bioslurry, Human (hired) labor, Seed, Irrigation, Tillage, Fertilizer, Pesticide, and Harvesting.

(b) Fixed cost items for both slurry based and nonslurry based boro rice: Land lease value and Land tax cost.

\section{Variable cost:}

Bio-slurry is one of the most important variable inputs for crop production. Due to more use of chemical fertilizer, the fertility of agricultural land is decreasing gradually. Farmers who use the bio-slurry in crop production did not measure accurately; their measurement is only based on eye contact and experience such as van per acre. They used on an average 3 ton/acre. That value is Tk. 1500. It contains 4.82 percent of total cost for owner operator, (Table 2).

Table 2 presents that slurry based crops growers used labor on an average 51 man-days/acre. Total cost of human (hired) labor amounted to Tk. 16575 per acre. It contains 53.35 percent of total cost for owner operator. On the other hand non-slurry based crop growers used labor on an average 58 man-days/acre. Total cost of human (hired) labor amounted to Tk. 18850 per acre. It contains 44.22 percent of the total cost. In non-slurry based crop more labor is required mainly for weeding.

For both (slurry and non-slurry based) boro production, the average seed cost was Tk.972 per acre.

Bio-slurry based land's water holding capacity is high, comparative less irrigation water is needed so irrigation cost is less. In the study area, irrigation water cost per acre was Tk. 4660 and Tk.4963 for slurry and non-slurry based rice production respectively.

Commonly used fertilizers by farmers were Urea, TSP and MoP, Gypsum, Zinc etc. For slurry based Boro cultivation the total fertilizers cost was Tk. 2205 per acre which shared 7.09 percent of its total cost and for non-slurry based crop cultivation the total cost of fertilizers was Tk. 4683 per acre which shared 13.42 percent of its total cost (Table 2).

Comparatively less pesticide was used in slurry based crop production, which contains Tk. 256 per acre and 0.82 percent of total cost. On the other hand Tk. 606 per acre was used for non-slurry based rice production, which occupied 1.73 percent of its total cost (Table 2).

Summation of the costs of variable inputs gave the result of total variable costs, which is Tk. 30814 for slurry based and Tk. 34627 for non-slurry based crop production. In percentage term total variable costs 99.19 and 99.28 of total cost for slurry and non-slurry based crops respectively were estimated (Table 2).

\section{Fixed Costs}

The householder owner is paid only the government issued lump sum land tax per acre.

\section{Estimation of Total Cost}

The total cost of slurry and non-slurry based Boro rice were estimated at Tk. 31064 and Tk. 34877, respectively (Table 2 ).

\section{Estimation of Gross Return}

Per acre return of slurry based crop was found Tk. 37120; include Tk. 33333 and 89.97 percent from main product and Tk. 3787 and 10.03 percent from straw. Per acre return of non-slurry based Boro rice was found Tk. 35302; include Tk. 31666 and 89.70 percent from main product and Tk. 3636 and 10.30 percent from byproduct observed in Table 2.

Per acre net returns for slurry based Boro rice was Tk. 6056 and non- slurry based Boro rice was Tk. 425 (Table 2).

BCR was calculated as a ratio of gross returns and gross costs. Table 2 reveals that the overall BCR (undiscounted) for slurry based crop is 1.19 and nonslurry based crop is 1.01 . It can clearly be seen from the above-mentioned discussions that in the study areas, for slurry based Boro rice and non-slurry based Boro rice cultivation were profitable and slurry based crop production is more profitable compare to non-slurry.

Boro rice is becoming a non-profitable business that has found in the study areas. Slurry practice for boro rice production was kept up the positive net return but nonslurry practice for boro rice production is near to break even points. 
Table 2 Costs and Returns of per acre Slurry and Non-slurry based Boro Production.

\begin{tabular}{lcccc}
\hline Cost/Return items & \multicolumn{2}{c}{$\begin{array}{c}\text { Bio-slurry based Boro rice } \\
\text { production }\end{array}$} & \multicolumn{2}{c}{$\begin{array}{c}\text { Non-slurry based Boro rice } \\
\text { production }\end{array}$} \\
\cline { 2 - 5 } & $\begin{array}{c}\text { Cost/Return } \\
\text { Tk/acre }\end{array}$ & $\begin{array}{c}\text { Percentage of } \\
\text { total cost }\end{array}$ & $\begin{array}{c}\text { Returns/Cost } \\
\text { Tk/acre }\end{array}$ & $\begin{array}{c}\text { Percentage of } \\
\text { total }\end{array}$ \\
\hline A. Variable Costs (Tk.) & & & & \\
Bio-slurry & 1500 & 4.82 & 0 & 0 \\
Human labor & 16575 & 53.35 & 18850 & 54.04 \\
Seeds & 972 & 3.12 & 972 & 2.79 \\
Irrigation & 4660 & 15.00 & 4963 & 14.23 \\
Ploughing & 2593 & 8.35 & 2593 & 7.43 \\
Fertilizer & 2205 & 7.09 & 4683 & 13.42 \\
Pesticide & 256 & 0.82 & 606 & 1.73 \\
Harvesting & 1351 & 4.34 & 1351 & 3.87 \\
Sub-total & 30112 & 96.94 & 33838 & 97.02 \\
Interest on OC & 702 & 2.25 & 789 & 2.26 \\
Total & 30814 & 99.19 & 34627 & 99.28 \\
B. Fixed Costs & & & 250 & 0.72 \\
Land use Cost & 250 & 0.83 & 34877 & 100 \\
C. Gross cost (A+B) & 31064 & 100 & & \\
D. Return & & & 31666 & 89.70 \\
Main product & 33333 & 89.97 & 3636 & 10.30 \\
By-product (Straw) & 3787 & 10.03 & 35302 & 100 \\
E. Gross Returns & 37120 & 100 & 425 & \\
F. Net Return (E-C) & 6056 & & 1.01 & \\
BCR (Tk/acre) & 1.19 & & & \\
\hline
\end{tabular}

Source: Authors (2016)

Nutritional value of Bio-slurry and chemical fertilizer based soil

Soil fertility is one of the most important factors for sustainable crop production. The agricultural scientists most often call organic matter as the life of the soils and also term it as the storehouse of the plant nutrients. Bioslurry can increase the physical, chemical and biological properties of the soils besides supplying essential nutrients to the crop plants. In this study, NPK tests have been conducted on slurry and non-slurry based soil for Boro rice production. Table 3 stated that the mean value of $\mathrm{N}, \mathrm{P}$ and $\mathrm{K}$ of slurry based soil are higher than chemical based soil in the selected areas. Islam (2006) found that the yield of vegetable crops is higher than those grown with recommended chemical fertilizers. The reduction of the use of chemical fertilizers is significant.

Table 3. NPK of slurry and chemical fertilizer based sol in Mymensingh district

\begin{tabular}{lrcc}
\hline Nutrient items & Slurry & Non-slurry & $\begin{array}{c}\text { t-statistic } \\
\text { value }\end{array}$ \\
\hline Nitrogen (\%) & 0.149 & 0.139 & 1.18 \\
Phosphorus (ppm) & 30.58 & 22.881 & 2.36 \\
Potassium (meq/100) & 1.58 & 0.301 & 6.61 \\
\hline
\end{tabular}

Source: Authors (2016)

The result of Nitrogen is not significantly difference of slurry and non-slurry based soil but case of Phosphorus and Potassium of slurry oriented soil are significantly different from non-slurry based soil. Haque (2013) and Islam (2011) also found better N (1.60\% and $1.42 \%)$ from digested bioslurry, respectively. Thus this slurry based soil is much usable for vegetable production due to sufficient level of Potassium presence in the soil. It is quite evident from the trial that bio-slurry had favorable influences in increasing the yields of the crops under study (Islam, 2006).

Considering the economic benefit, soil acceptance and finally environmentally this slurry practice is convenient. The more practice of slurry the more sustainable agricultural production. Slurry based soil is being played a sustainable role for crop production in Bangladesh.

\section{Evaluation of social acceptability and perception of slurry practices}

Globalization and developments in science and technology provide a very wide impact on all sectors of human life. The growth of technology allows simplicity for people in living activities. Bio-slurry practices for sustainable development of agricultural land are one result of technological advances in the agricultural field. In view of the size and its operation, bio-slurry is a very practical fertilizer, farmer use bio-slurry to assist their crop production. It also makes the consumer faced with various choices of brands, so the organic fertilizer (bioslurry) manufacturers need to know the tastes and 
desires of consumers in order to create and sell organic products that can be liked by consumers in one way is to analyze consumer attitudes toward products based on their assessment bio-slurry of various attributes that exist in the product.

It is clear that the attitude value of using bio-slurry is 51.35 and the attitude value of using chemical fertilizer is 27.56 (Table 3). It indicates that the attitude value of using bio-slurry is greater than the attitude value of using chemical fertilizer. So farmer has a positive attitude to use bio-slurry in rice production as well as bio-slurry is socially more preferable and acceptable in crop production.

Table 4. User attitude estimation for bio-slurry and chemical fertilizer

\begin{tabular}{lcccccc}
\hline Attributes & \multicolumn{3}{c}{ For bio-slurry } & \multicolumn{3}{c}{ For chemical fertilizer } \\
\hline & bi & ei & biei & bi & ei & biei \\
Organic product & 4.93 & 2.80 & 13.80 & 1.00 & -2.80 & -2.80 \\
Increase soil fertility & 4.87 & 2.77 & 13.49 & 1.40 & -2.50 & -3.50 \\
Environmental friendly & 4.90 & 2.57 & 12.59 & 1.46 & -2.40 & -3.50 \\
Cost minimize & 4.77 & 2.23 & 10.64 & 2.80 & -0.43 & -1.20 \\
By proper management it can free human & 3.87 & 1.47 & 5.69 & 1.67 & -2.53 & -4.23 \\
from many water disease & & & & & & \\
Dirty & 2.73 & -0.33 & -0.091 & 4.13 & 2.23 & 9.21 \\
Bad smell compare to others & 3.97 & -0.47 & -1.87 & 3.10 & 0.16 & 0.05 \\
Carrying cost is high & 2.10 & -1.03 & -2.16 & 4.23 & 2.07 & 8.76 \\
Retention time is long & 3.06 & 0.23 & 0.70 & 5.00 & 2.77 & 13.85 \\
Neighbors are motivated to install biogas & 3.86 & 1.43 & 5.51 & 2.8 & -0.03 & -0.08 \\
plant & & & & & & \\
Need more space & 2.50 & -0.57 & -1.43 & 4.53 & 2.43 & 11.00 \\
\hline A0 & $\sum$ biei & & 51.35 & \multicolumn{4}{c}{$\sum$ biei } & 27.56 \\
\hline
\end{tabular}

Slurry has a positive significant relationship with biogas user by which households can have increased the total output. That implies overall impact of slurry have found on total Boro production increasing due to increase soil fertility, with less chemical fertilizers and labor use, as well as reduce $\mathrm{CO}_{2}$ emission, reducing the use of dry dung cake etc (Kabir, et. al., 2013).

The attitude on slurry practice being an agricultural technology is neglected and under estimated of nutritional value. The farmers are not much motivated due to absence of government proper policy, less practice of organic agricultural products, less experience of handing the slurry, less research conduct Bangladesh.

\section{Conclusion}

The soil fertility status of Bangladesh is really frustrated. Soil fertility in Bangladesh are depleted due to over practice of chemical fertilizer as well as less use of organic fertilizer. The slurry has contained of very nutrient elements that performs better result compare to the non-slurry practice in the study areas. Slurry practice would supplementary added to overall soil fertility in Bangladesh. It will enhance to increase the crop production as well as make good soil health. The slurry practice also are performed better rice production which also make boro rice is a profitable enterprise. Farmers attitude on slurry practice is also reflected a better result compare to chemical fertilizers. Land for agricultural crops production will have more scientific as well as sustainable managed by using the slurry practice in ngladesh. Though, it is taking much more time to popularity of slurry practice in Bangladesh due to absence of institutional regularity bodies, lack of awareness on nutritional value of slurry, lack of proper technology used for handling the slurry etc, It needs more prompt policy to accelerate the bio-slurry practice over the country where Government, Non-government and private sector will have strong commitments to the slurry users.

\section{References}

BARC. 2005. Fertilizer recommendation guide. Bangladesh Agricultural Research Council, Farmgate, Dhaka-1215, 260p.

Islam M.S. 2006. Use of bioslurry as organic fertilizer in Bangladesh agriculture. Paper presented in the International Workshop, Bangkok, Thailand, 27-28 September 2006.

Islam, A.A.B.M. 2013. Bio slurry Ultimate Choice of Biofertilizer. Open Access Scientific Reports.Volume 2 - Issue 4 • 2013 https://www.omicsonline.org/scientific-reports/JBES-SR738.pdf

Islam, M.F. 2011. Linking Bio-energy, Bio-slurry and Composting. http://www.fao.org/fileadmin/templates/rap/files/meetings/2 011/110602_linking_bio-energy.pdf

Kabir, H., Musharraf, M., Haque, M.M. and Khan, M. 2015. Technical efficiency of Boro rice production in Bangladesh: A case of bio-slurry application J. Bangladesh Agril. Univ. 13(1): 101108.

Mendoza, T. 2002. Impact Analysis of Organic Farming in Rice AgroEcosystems in the Philippines. First RDA/ARNOA International Conference, RDA and Dankook University of Korea, November 12-15, 2002. 